\title{
Exploratory Factor Analysis: Motivation for Learning
}

\author{
Untung Desy Purnamasari ${ }^{1}$, Muamar Surawidarto ${ }^{1}$, Dedek Andrian², Samsul \\ Hadi $^{1}$, and Edi Istiyono ${ }^{1}$ \\ ${ }^{1}$ Yogyakarta State University, Indonesia \\ ${ }^{2}$ Riau Islamic University, Indonesia
}

\section{Abstract}

Learning motivation is an important aspect of the learning process because it promotes performance goals and maintains learning achievement. This study aims to determine the factor that can affect learning motivation of student at Yogyakarta State University Postgraduate Program. This research was quantitative method with explorative descriptive approach. Technique of collecting data using questionnaire method. Total of 150 postgraduate students at Yogyakarta State University voluntarily participated

Corresponding Author: Untung Desy Purnamasari untungdesypurnamasari.2017 @student.uny.ac.id

Received: 18 January 2019 Accepted: 24 March 2019 Published: 31 March 2019 Publishing services provided by Knowledge E

(c) Untung Desy Purnamasari et al. This article is distributed under the terms of the Creative Commons Attribution License, which permits unrestricted use and redistribution provided that the original author and source are credited.

Selection and Peer-review under the responsibility of the ICEST 2018 Conference Committee.

\section{G OPEN ACCESS}

in answering the learning motivation questionnairs. Analysis of data used Exploratory Factor Analysis procedure to identify factors that can affect students' motivation to study. Based on data analysis obtained six factors, there are diligent in doing the task, discipline in following lecture, discipline and frequency in learning, encouragement to learn and achievement, doing the task by self, and time for learning. The study concludes that the most influential factor is diligent in doing the task.

\section{Keywords: Learning Motivation, Exploratory Factor Analysis}

\section{Introduction}

Learning motivation is an important aspect of learning process because it promotes performance goals and maintains learning achievement [1]. Achievement motivation had an effect on student motivation [2]. Motivation to learn has a relationship with learning achievement [3]. Motivation to learn affects student learning outcomes [4]. The motivation of learning is positively related to academic performance [5]. Motivation to learn has a significant influence on student learning, which is a major determinant of academic performance and creativity [6]. Learning motivation is an important factor that affects (maintains and directs) learning behavior and learning outcomes [7]. Motivation to learn is the main thing in achieving performance [8].

There are two types of motivation, learning motivation can arise from within (intrinsic) and from outside individual (extrinsic) [9]. Intrinsic motivation to learn indirectly and 
positively related to academic performance [10]. Motivation that emerges from within the individual will be more stable and steady when compared with learning motivation that arise because of environmental infuences (motivation from outside) [11]. Highly motivated students tend to be more active in their efforts to improve their performance. Learning achievement is influenced by two factors: internal factors and external factors. Internal factors are factor that originate from within individuals such as physical factors, psychology, and fatigue factors. While external factors are all factors that come from outside such as family environment, school and community [12]. In line with that opinion, motivation is known as an important factor affecting student performance. Students who believe they are competent show greater effort and determination in academic performance. Conversely, less student motivation tends to show excessive anxiety to be ready to engage in academic activities. As a result, it is necessary to conduct research that focuses not only on improving techniques but also on motivation and ultimately on self-motivation [13].

This study aims to determine the factor that can affect learning motivation of student at Yogyakarta State University Postgraduate Program. Motivation to learn a person can be seen from the discipline in following the lecture, the level of attention in following the lecture, the frequency of learning at home, and others. Reality we can see, a student who is equally disciplined in entering college, and have the same attention at the time of studying, but have different achievements. Sometimes the condition that happens is that students who rarely attend college actually have a high achievement compared with students who always go to college.

The condition of morbidity is what raises the question how the role of learning motivation in achievement of learning achievement. The low motivation makes the students have no motivation to like the lecture material so that it will be difficult to accept and master the course. This shows that the high level of learning achievement can be influenced by the high and low motivation of student learning or can also be said student achievement that is not optimal this tend to be influenced by less optimal student learning motivation. In this research, the researcher uses exploratory factor analysis for factors that can influence student's learning motivation.

The exploratory factor analysis is a complex statistical method that is an integral part of many fields of research. Using factor analysis requires researchers to make some decisions, each of which affects the resulting solution [14]. EFA is an explorative method used to generate theory; researchers used EFA to search for a smaller set of latent $k$ factors to represent a larger set of $j$ variables [15]. 


\section{Methods}

This research used quantitative method with explorative descriptive approach. Quantitative descriptive research is a study that provides an overview of a phenomenon in the current more broadly [16]. The sample were 150 postgraduate students at Yogyakarta State University.

Data collection techniques used questionnaires. Data analysis technique used in this research is factor analysis model with Exploratory Factor Analysis. Exploratory factor analysis is done by using computer program, Statistical Package for Social Sciences (SPSS).

\section{Result and Discussion}

Exploratory Factor Analysis (EFA) is a statistical technique that explores the underlying factors of a variable through factor rotation on the basis of factor loading values so that researchers assume that some indicators may be related to several factors [17]. The reason for using EFA is because the researcher wants to explore widely the factors that influence student's learning motivation in Postgraduate Program by letting the research variables form their own patterns.

This study consisting of 21 items and examined as the factors that allegedly affect the motivation of Yogyakarta State University postgraduate students. To perform a factor analysis it is necessary to perform a pre-requisite analysis test to determine whether the data to be analyzed is correct or not. There are 3 prerequisite test analyzes namely Barlett's Test of Spherecity, Kaiser-Meyer-Olkin Test (KMO), and Measure of Sampling Adequacy (MSA) Test [17].

Barlett's Test of Spherecity test aims to see the normality of data with a significance level of less than 0.05 [18]. Based on Barlett's Test of Spherecity test for 21 indicator statistics obtained value 896,779 with a significance level of 0.000 , which means that among all indicators of the statement there is correlation so feasible for factor analysis.

The Kaiser-Meyer-Olkin (KMO) test is used to decide whether or not a data can be analyzed by factor analysis with KMO values. If the KMO value is above 0.5 then the data is feasible to use [18]. Based on the calculation with SPPS Version 18, the value of $\mathrm{KMO}$ obtained is 0.779 , because the value of $\mathrm{KMO}$ is high or more than 0.5 then factor analysis is feasible to be used for this research.

The next step is the Measure of Sampling Adequacy (MSA) test. MSA values actually have the same meaning as $\mathrm{KMO}$, except MSA rate each item and not for the whole. 
TABLE 1: KMO and Bartlett's Test Score.

\begin{tabular}{|c|c|c|}
\hline \multicolumn{3}{|c|}{ KMO and Bartlett's Test } \\
\hline \multicolumn{2}{|c|}{ Kaiser-Meyer-Olkin Measure of Sampling Adequacy. } & .779 \\
\hline \multirow[t]{3}{*}{ Bartlett's Test of Sphericity } & Approx. Chi-Square & 896.779 \\
\hline & df & 210 \\
\hline & Sig. & .000 \\
\hline
\end{tabular}

Based on the results of MSA calculations with SPSS Software Version 18 shows all items have MSA values greater than 0.5. The MSA values for each variable are shown in Table 2.

TABLE 2: MSA values of each variable on data reduction.

\begin{tabular}{|c|c|}
\hline Variable Names & MSA Values \\
\hline Item1 & 0,760 \\
\hline Item2 & 0,773 \\
\hline Item3 & 0,795 \\
\hline Item4 & 0,818 \\
\hline Item5 & 0,813 \\
\hline Item6 & 0,838 \\
\hline Item7 & 0,802 \\
\hline Item8 & 0,800 \\
\hline Item9 & 0,724 \\
\hline Item10 & 0,791 \\
\hline Item11 & 0,802 \\
\hline Item12 & 0,806 \\
\hline Item13 & 0,723 \\
\hline Item14 & 0,807 \\
\hline Item15 & 0,702 \\
\hline Item16 & 0,756 \\
\hline Item17 & 0,816 \\
\hline Item18 & 0,692 \\
\hline Item19 & 0,770 \\
\hline Item20 & 0,708 \\
\hline Item21 & 0,774 \\
\hline
\end{tabular}

It shows that all variables can be said to significantly affect student's learning motivation. 
After performing the pre-requisite analysis test, the next step is to determine the number of factors by means of factor extraction. This process is used to group a number of factors by issuing items whose eigenvalue is less than 1.0. According to Johnson \& Wichern (2007: 482), the determination of the number of factors viewed from eigenvalue that has values above 1.0. Eigenvalue is the total variance contained in each factor. Analysis to find eigenvalue done using SPSS Software Version 18 forming of 6 factors. The results of factors extraction and distribution of items on each factor formed can be seen in Table 3 below:

TABLE 3: Distribution of factor components.

\begin{tabular}{|l|c|c|c|}
\hline & Eigenvalue & \% of Variance & Cumulative \\
\hline 1 & 5.129 & 24.424 & 24.424 \\
\hline 2 & 2.054 & 9.783 & 34.207 \\
\hline 3 & 1.784 & 8.496 & 42.702 \\
\hline 4 & 1.388 & 6.607 & 49.309 \\
\hline 5 & 1.307 & 6.224 & 55.533 \\
\hline 6 & 1.044 & 4.973 & 60.506 \\
\hline
\end{tabular}

Total Variance Explained shows the value of each variable being analyzed. The "total" column on these eigenvalues greater than 1 indicates the number of factors formed. In this case there are six values of eigenvalues whose value is more than 1 , respectively 5,$129 ; 2.054 ; 1,784 ; 1,388 ; 1.307$ and 1.044 . This means that the 21 variables analyzed can be grouped into 6 major factor components. In Extraction Sums of Squared Loadings gives the meaning of the number of variants obtained is 6 .

If from 21 variables only extracted into one factor then the variables that can be explained as $(5,129 / 21) \times 100 \%=24,424 \%$. If from 21 variables only extracted into two factors only then the variant which can be explained by two factors are $(2,054$ / 21) $x$ $100 \%=9,783 \%$. If both variations accumulate will be able to explain $24.424 \%+9.783 \%$ $=34.207 \%$ of the 21 variables (see cumulative column\% in Extraction Sums Of Square Loadings). But if all (21 variables) are extracted into six factors it will be able to explain $60.506 \%$ of the total factor.

The first factor is the strongest factor influencing student learning motivation, consisting of item 7, 8, and 9. These three items receive loadings of.747;.723; and.780. This factor is labelled as diligent in doing the task. This is consistent with opinion that diligent in doing the task is very important for students in achieving [20]. The second factor consists of item 4, 5 and 6 which receive loadings ranging from. 649 to.730. This factor labelled as discipline in following lecture. The third factor consists of item 1, 2, 3 and 13 
which receive loadings ranging from.649 to.730. This factor labelled as discipline and frequency in learning. The fourth factor are item 19, 20, and 21. These three items receive loadings of.747;.723; and.780. This factor is labelled as encouragement to learn and achievement. This is consistent with opinion that student encouragement to learn and achievement is key for students to get positive results including good results because students have high motivation [21]. The fifth factor item 16 and 17. These two items receive loadings which are.731; and.733 respectively. This factor is labelled as doing the task by self. The sixth factor is the weakest factor comprising item 12 which receive loading of.787. Thus, this factor labelled as time for learning. This is consistent with the research by Ukpong and George that students who have long time to study can affect student achievement. Students who have a long time to study have a better achievement than students who have short learning time [22].

\section{Conclusion}

Based on the result of research, data analysis, and discussion, it can be concluded that there are 6 factors that influence the motivation of students at Postgraduate Program of Yogyakarta State University, there are diligent in doing the task, discipline in following lecture, discipline and frequency in learning, encouragement to learn and achievement, doing the task by self, and time for learning.

\section{Acknowledgement}

I would like to thank to Indonesia Endowment Fund for Education (LPDP) Ministry of Finance Republic Indonesia for giving supporting author by scholarship.

\section{References}

[1] J. Wyss, S. Lee, T. Domina, and M. Macgillivray, "Cotton Island: Students ' Learning Motivation Using a Virtual World *," Decis. Sci. J. Innov. Educ., vol. 12, no. 3, pp. 219233, 2014.

[2] M. Verkuyten, J. Thijs, and K. Canatan, "Achievement motivation and academic performance among Turkish early and young adolescents in The Netherlands.," Genet. Soc. Gen. Psychol. Monogr., vol. 127, no. 4, pp. 378-408, 2001.

[3] A. R. Artino, J. S. La Rochelle, and S. J. Durning, "Second-year medical students' motivational beliefs, emotions, and achievement," Med. Educ., vol. 44, pp. 1203-1212, 
2010.

[4] T. Hsieh, "Motivation matters? The relationship among different types of learning motivation, engagement behaviors and learning outcomes of undergraduate students in Taiwan," High Educ., vol. 68, pp. 417-433, 2014.

[5] K. M. Stegers-jager, J. Cohen-schotanus, and A. P. N. Themmen, "Motivation, learning strategies, participation and medical school performance," Med. Educ., vol. 46, pp. 678-688, 2012.

[6] W. Hu, X. Jia, J. A. Plucker, and X. Shan, "Effects of a Critical Thinking Skills Program on the Learning Motivation of Primary School Students," Roeper Rev., vol. 38, pp. 70-83, 2016.

[7] J. C. Sun and K. Lee, "Which Teaching Strategy is Better for Enhancing AntiPhishing Learning Motivation and Achievement? The Concept Maps on Tablet PCs or Worksheets?," Educ. Technol. Soc., vol. 19, no. 4, pp. 87-99, 2016.

[8] S. Indreica and C. Truta, "The Log As a Tool For Stimulating Learning Motivation," Bull. Transilv., vol. 10, no. 2, pp. 149-154, 2017.

[9] S.-C. Ngan and L. Kris, "Exploratory Network Analysis of Learning Motivation Factors in e-Learning Facilitated Computer Programming Courses," Asia-Pacific Edu Res, vol. 24, no. 4, pp. 705-717, 2015.

[10] J. M. Froiland and F. C. Worrell, "Intrinsic motivation, learning goals, engagement, and achievement in a diverse high school," Psychol. Sch., vol. 53, no. 3, pp. 321 336, 2016.

[11] A. C. Garn and J. L. Jolly, "High Ability Students 'Voice on Learning Motivation," J. Adv. Acad., vol. 25, no. 1, pp. 7-24, 2014.

[12] D. Urhahne, S. Chao, M. L. Florineth, S. Luttenberger, and M. Paechter, "Academic self-concept, learning motivation, and test anxiety of the underestimated student," Br. J. Educ. Psychol., vol. 81, pp. 161-177, 2011.

[13] S. Surastina and F. Dedi, "Examining Academic Writing Motivation of Prospective Indonesian Language Teachers Using Exploratory Factor Analysis," Int. J. Instr., vol. 11, no. 2, pp. 15-24, 2018.

[14] C. J. Gaskin and B. Happell, "International Journal of Nursing Studies On exploratory factor analysis: A review of recent evidence, an assessment of current practice, and recommendations for future use," Int. J. Nurs. Stud., vol. 51, pp. 511-521, 2014.

[15] R. K. Henson and J. K. Roberts, "Use of Exploratory Factor Analysis in Published Research: Common Errors and Some Common Improved Practice," Educ. Psychol. Meas., vol. 66, pp. 393-416, 2006. 
[16] J. Creswell, Education Research, Planning, Conducting and Evaluating Quantitative and Qualitative Research, 4th ed. Boston: Pearson, 2012.

[17] A. Panter, K. Swygert, W. Dahlstrom, and J. Tanaka, "Factor Analytic Approaches to Personality Item-Level Data," J. Pers. Assess., vol. 68, no. 3, pp. 561-589, 1997.

[18] H. F. Kaiser, "An Index of Factorial Simplicity," Psychol. Sch., vol. 39, no. 1, pp. 31-36, 1974.

[19] R. A. Johnson and D. W. Wichern, Applied Multivariate Statistical Analysis. 2007.

[20] B. M. Galla, B. D. Plummer, R. E. White, D. Meketon, S. K. D’Mello, and A. L. Duckworth, "The Academic Diligence Task (ADT): Assessing individual differences in effort on tedious but important schoolwork," Contemp. Educ. Psychol., vol. 39, no. 4, pp. 314325, 2014.

[21] S. A. Sasuk, N. Kudthalang, and W. Rakrai, "Encouragement of Students ' Learning Achievements and Their Attitudes Towards Science Through The STEM Education Instructional Method in Science Class at The 9th Grade Level," Eur. J. Educ. Stud., vol. 3, no. 5, pp. 521-539, 2017.

[22] D. E. Ukpong and I. N. George, "Length of Study-Time Behaviour and Academic Achievement of Social Studies Education Students in the University of Uyo," Int. Educ., vol. 6, no. 3, pp. 172-178, 2013. 